University of Nebraska - Lincoln

DigitalCommons@University of Nebraska - Lincoln

Publications from USDA-ARS / UNL Faculty

U.S. Department of Agriculture: Agricultural

Research Service, Lincoln, Nebraska

1999

Comparison of Precipitation Catch Between Nine Measuring

Systems

Clayton L. Hanson

USDA-ARS

Gregory L. Johnson

USDA-NRCS

Albert Rango

USDA-ARS

Follow this and additional works at: https://digitalcommons.unl.edu/usdaarsfacpub

Part of the Agricultural Science Commons

Hanson, Clayton L.; Johnson, Gregory L.; and Rango, Albert, "Comparison of Precipitation Catch Between Nine Measuring Systems" (1999). Publications from USDA-ARS / UNL Faculty. 470.

https://digitalcommons.unl.edu/usdaarsfacpub/470

This Article is brought to you for free and open access by the U.S. Department of Agriculture: Agricultural Research Service, Lincoln, Nebraska at DigitalCommons@University of Nebraska - Lincoln. It has been accepted for inclusion in Publications from USDA-ARS / UNL Faculty by an authorized administrator of DigitalCommons@University of Nebraska - Lincoln. 


\title{
Comparison of Precipitation Catch between Nine Measuring Systems
}

\author{
By Clayton L. Hanson, ${ }^{1}$ Member, ASCE, Gregory L. Johnson, ${ }^{2}$ and Albert Rango ${ }^{3}$
}

\begin{abstract}
A site was established by the U.S. Department of Agriculture-Agricultural Research Service on the Reynolds Creek Experimental Watershed in southwest Idaho in the fall of 1987 and operated through the spring of 1994, to compare precipitation catch between nine precipitation-measuring systems. This site was established as a part of the World Meteorological Organization's program to compare current national methods of measuring solid precipitation (snow), so the primary emphasis of this study was the measurement of snowfall. Over seven seasons, four of the systems measured snowfall and total catch, which included snow, mixed snow and rain, and rain events, within $4 \%$ of the Wyoming shielded gauge, which had the greatest total catch. These measuring systems were the Alter shielded gauge and the dual-gauge system from the United States, the doublefence shielded gauge from Russia, and the Nipher shielded gauge from Canada. The unshielded universal recording gauge that was mounted with its orifice at $3.05 \mathrm{~m}$ had the least catch in all precipitation categories, which amounted to $24 \%$ less snow, $18 \%$ less mixed snow and rain, and $10 \%$ less rain than was measured by the Wyoming shielded gauge.
\end{abstract}

\section{INTRODUCTION}

There are numerous systems of measuring containers with and without shielding that have been used or are now being used to measure snowfall in the United States and around the world (Neff 1977; Sevruk and Klemm 1989). Because of the interest throughout the world in issues such as climate change and global weather modeling, Arnell et al. (1996) suggest that there is a need for more extensive climatic data sets and climatic monitoring networks. As noted by Nicholls et al. (1996), reliable global data sets are hard to obtain because of the known problems (primarily undercatch) associated with measuring precipitation. Undercatch of snowfall by gauges that are not protected naturally, as they are in forest clearings, is one of the major problems in obtaining accurate point measurements. The problem of measuring snowfall under windy conditions has been documented extensively (Kurtyka 1953; Warnick 1953; Weiss and Wilson 1958; Allis et al. 1963; Garstka 1964; Israelson 1967; Larson 1971; Neff 1977; Hanson et al. 1996). Therefore, in 1985, the Commission for Instruments and Methods of Observation of the World Meteorological Organization recommended that an international study be established to compare current national methods of measuring solid precipitation (snow) (Goodison et al. 1989). In 1986, the U.S. Department of AgricultureAgricultural Research Service, Northwest Watershed Research Center agreed to establish an intercomparison site on the Reynolds Creek Experimental Watershed (RCEW) in southwest Idaho (Robins et al. 1965; Flerchinger et al. 1994). The RCEW was chosen as an intercomparison site because the climate there represents the inland mountainous area of the Pacific Northwest, and most of the meteorological instruments required for the study were available on-site.

${ }^{1}$ Agric. Engr., USDA/ARS, Northwest Watershed Res. Ctr., 800 Park Blvd., Plaza IV, Ste. 105, Boise, ID 83712.

${ }^{2}$ Appl. Climatologist, USDA/NRCS, Nat. Water and Climate Ctr., 101 SW Main St., Ste. 1600, Portland, OR 97204.

${ }^{3}$ Res. Hydro., Hydro. Lab., USDA/ARS/BARC-W, Bldg. 007, Room 104, Beltsville, MD 20705.

Note. Discussion open until June 1, 1999. To extend the closing date one month, a written request must be filed with the ASCE Manager of Journals. The manuscript for this paper was submitted for review and possible publication on March 25, 1997. This paper is part of the Journal of Hydrologic Engineering, Vol. 4, No. 1, January, 1999. (CASCE, ISSN 1084-0699/99/0001/0070-0075/\$8.00 + \$.50 per page. Paper No. 15415 .

\section{STUDY SITE}

\section{Location}

The Reynolds Creek intercomparison site $\left(43^{\circ} 12^{\prime} \mathrm{N}\right.$, $\left.116^{\circ} 45^{\prime} \mathrm{W}\right)$ is at an elevation of $1,193 \mathrm{~m}$ near the north end of the RCEW (Fig. 1). The 234- $\mathrm{km}^{2} \mathrm{RCEW}$ is located on the north flank of the Owyhee Mountains, approximately $65 \mathrm{~km}$ southwest of Boise, Idaho (Stephenson 1977). The site is on gently sloping, sagebrush rangeland that is surrounded by rangeland and irrigated hay fields. Mean annual precipitation is $271 \mathrm{~mm}$ (1962-1993), with a mean maximum monthly amount of $31 \mathrm{~mm}$ in November and a mean minimum monthly amount of $8 \mathrm{~mm}$ in July. However, it should be noted that mean monthly amounts for November-June are all between 22 and $31 \mathrm{~mm}$, with a June mean of $30 \mathrm{~mm}$.

The mean annual daily temperature at the site is $8.1^{\circ} \mathrm{C}$, with a January mean of $-1.9^{\circ} \mathrm{C}$ and a July mean of $20.3^{\circ} \mathrm{C}$. Mean daily wind speed is $2.3 \mathrm{~m} / \mathrm{s}$, varying from $1.8 \mathrm{~m} / \mathrm{s}$ in October to $2.8 \mathrm{~m} / \mathrm{s}$ in April. The predominate wind direction is southerly for November-February, the months with the greatest snowfall.

\section{Instrumentation}

As shown in Fig. 2, the intercomparison precipitation gauges were installed near the RCEW's climatological station. This site was selected to take advantage of existing instruments and climatological records. Because only four new gauges had to be installed for this study (four were already in place), they were arranged so that all gauge locations followed the suggested World Meteorological Organization design as closely as possible, considering the predominantly southwest wind during precipitation events and the location of buildings to the north of the gauges.

The following nine gauging systems were used in this study (see Fig. 3): (1) The Belfort universal recording gauge (orifice at $2.2 \mathrm{~m}$ ) with a Wyoming shield (WYO; Rechard 1975); (2) the Russian double-fence intercomparison reference (DFIR) gauge, consisting of a shielded Tretyakov (TRET) gauge (orifice at $3.0 \mathrm{~m}$ ) with two concentric wooden outer shields; (3) the Russian TRET gauge (orifice at $2.0 \mathrm{~m}$ ) with shield; (4) the Canadian Nipher shielded snow gauge (CAN) (orifice at 1.6 m) (Canadian Department of Environment 1985); (5) the U.S. National Weather Service 8-in. nonrecording gauge (orifice at $0.94 \mathrm{~m}$ ) without a shield (NATUNSHLD); (6) the Belfort universal recording gauge (orifice at $1.4 \mathrm{~m}$ ) with an Alter shield with unconstrained baffles (NATSHLD; Alter 1937); (7) the Belfort universal recording gauge (orifice at $3.05 \mathrm{~m}$ ) without 


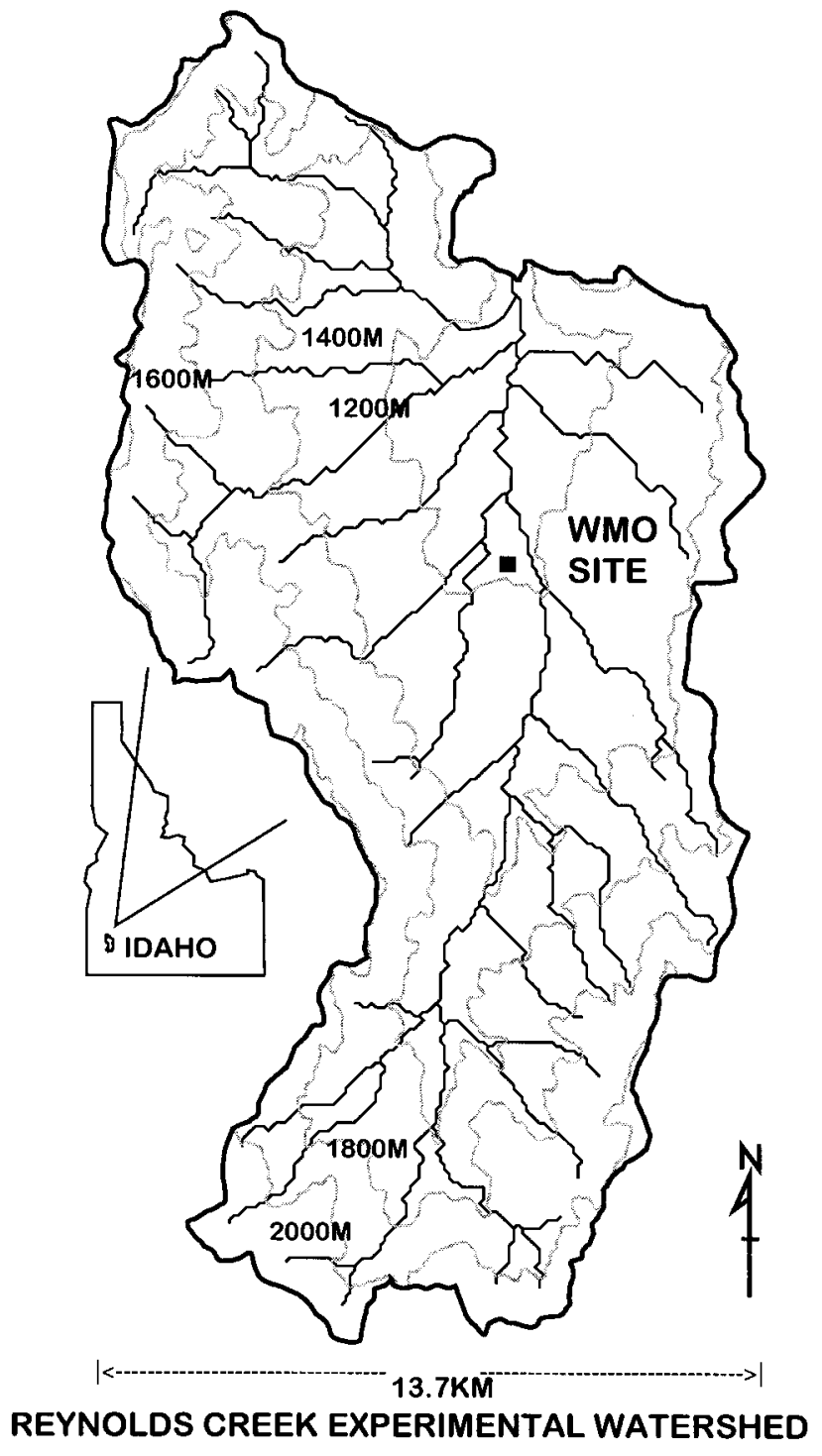

FIG. 1. WMO Site on RCEW, Idaho

a shield (BELUNSHLD); (8) the Belfort universal recording gauge (orifice at $3.05 \mathrm{~m}$ ) with an Alter-type shield with the shield's baffles individually constrained at an angle of $30^{\circ}$ from the vertical (BELSHLD); and (9) the dual-gauge (DUAL-GAUGE; Hamon 1973; Hanson 1989) configuration that is discussed in the next section.

\section{DATABASE}

The project began during the late fall of 1987 and continued during each winter through the spring of 1994. The amount of precipitation during each storm event caught by the container-type gauges was determined by weighing the containers rather than melting the snow and measuring the water in separate measuring cylinders. This prevented erroneous measurement reductions caused by water retention on the sides of the containers. These weight values then were converted to millimeters of water. The amount of precipitation measured by the universal weighing gauges was retrieved from their respective recorder charts for the same time periods as those of the container-type gauges. Based on field observations, the data were divided into snow, mixed snow and rain, and rain events. The only data used in this study were from those events when the WYO gauge caught $1.5 \mathrm{~mm}$ and greater because reliable data could be obtained from all gauges at this depth of precipitation.

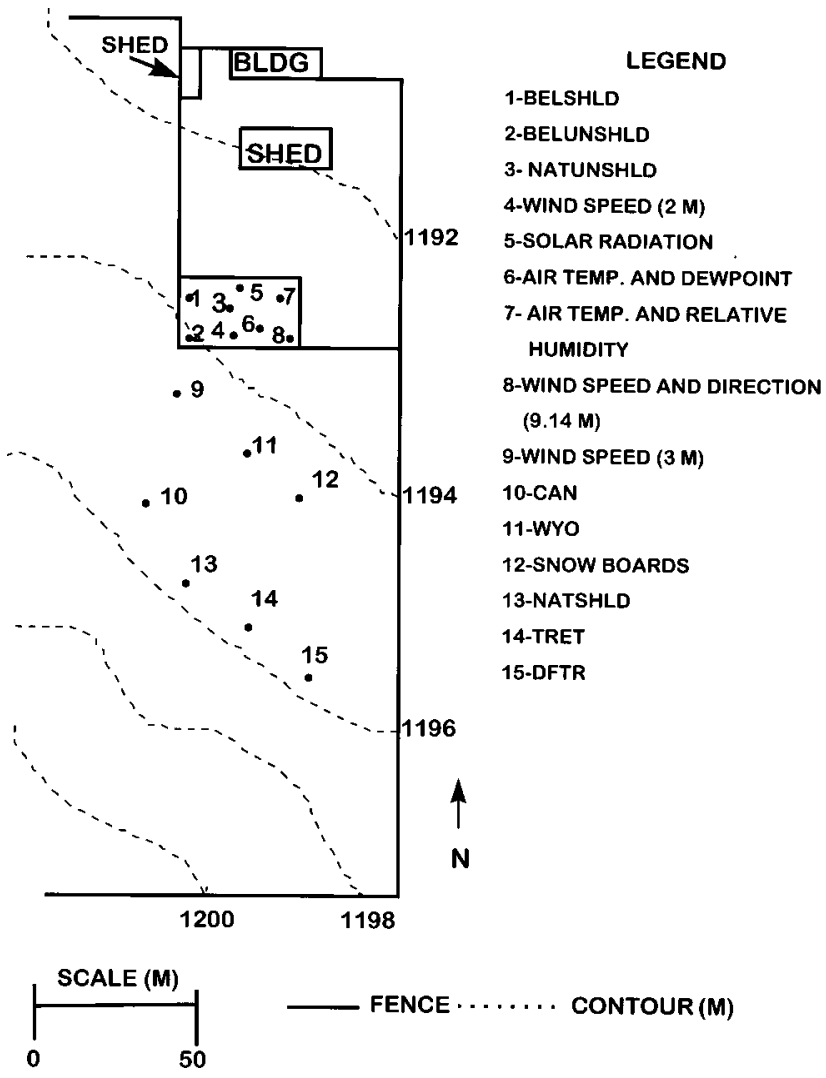

FIG. 2. Location of Precipitation Gauges and Other Instruments on WMO Site

Computed precipitation from the DUAL-GAUGE system was obtained from the following equation:

$$
A=S^{B} U^{(1-B)}
$$

where $A=$ computed precipitation; $U=$ BELUNSHLD precipitation; $S=$ BELSHLD precipitation; and $B=$ a coefficient that Hamon (1973) found to be 1.70. Hamon (1973) found the $B$ remained reasonably constant for wind speeds up to $13.4 \mathrm{~m} / \mathrm{s}$ for both rain and snow.

The proportional relationship between individual gauge catch and the WYO catch was used as the measure of how well each gauge represented precipitation catch. A ratio of 1.0 indicated that identical amounts were measured by individual gauges and the WYO. The Wilcoxon signed-rank test (Siegel 1956; Snedecor and Cochran 1967; StatMost 1995) was used to determine if the mean catch between each gauge type was significantly different $(\alpha=0.05)$.

Regression analyses were used to evaluate the relationship between wind speed and the ratio between other gauges catch and WYO catch for each of the three precipitation categories. The 0.10 probability level was used to test if the regression slopes and intercepts were significantly different from 0.0 and 1.0 , respectively.

\section{RESULTS AND ANALYSIS}

\section{Gauge Catch}

Table 1 is a summary of gauge catch for the study period of 1987-1994. The WYO catch amounts were used as the base values in this study because the WYO had the greatest total catch during this study. These results agree with a previous study at this same site by Hanson (1989), which found that the WYO had a slightly greater total precipitation catch than the DUAL-GAUGE system. 
(a)

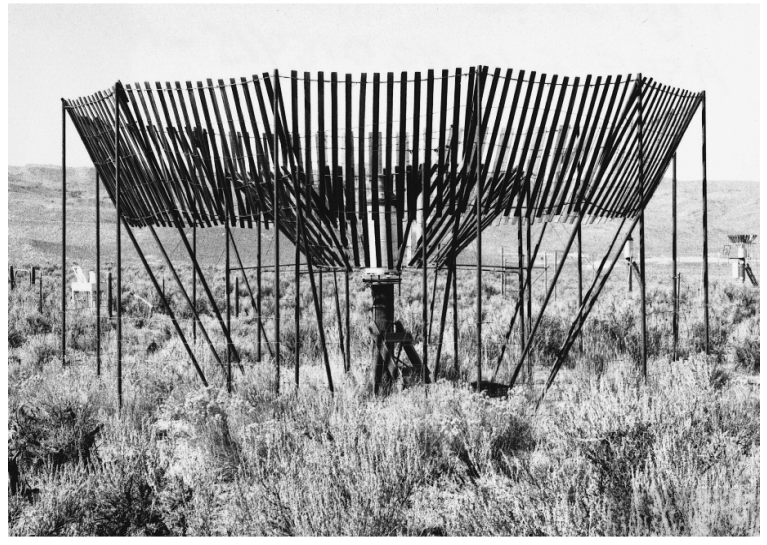

(c)

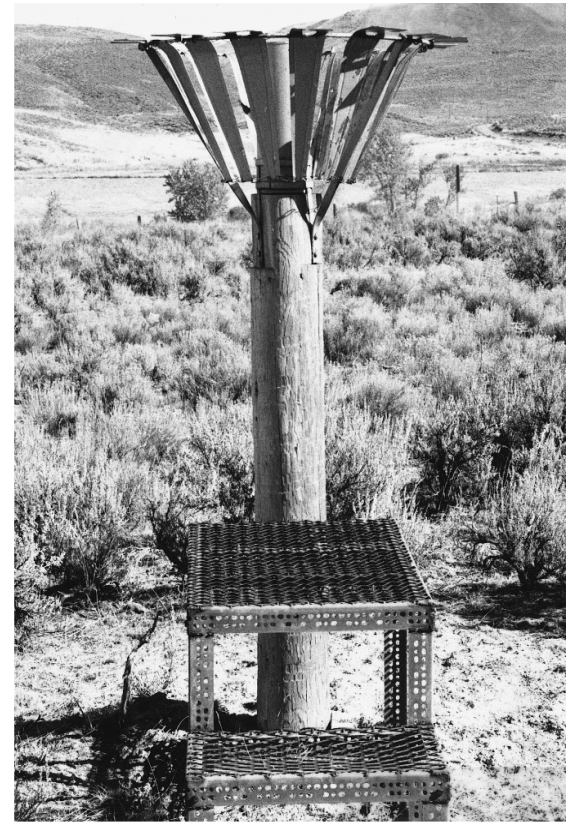

(e)

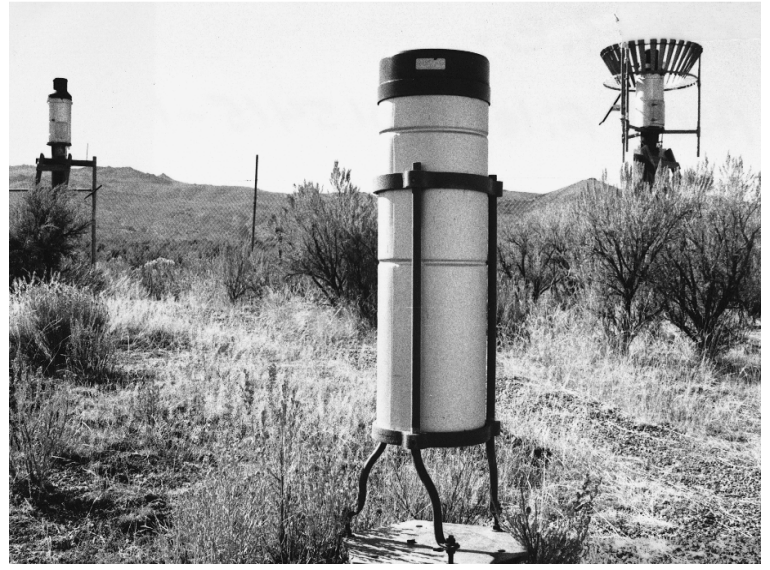

(b)

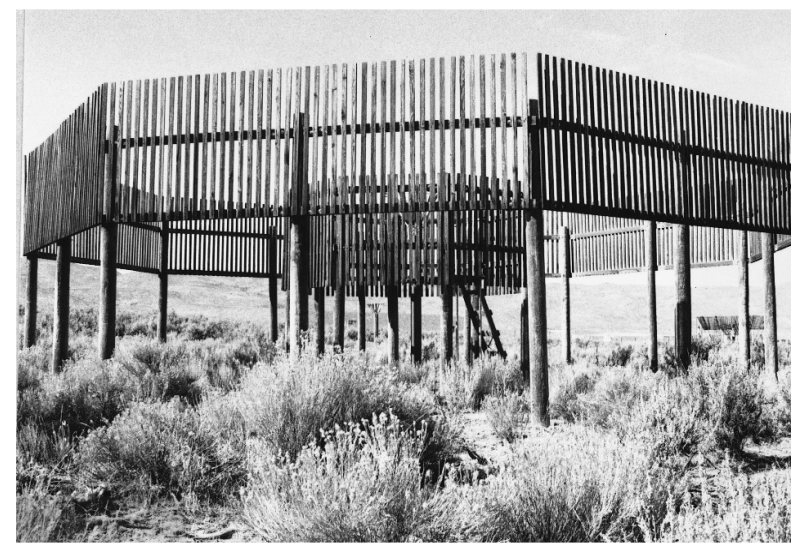

(d)

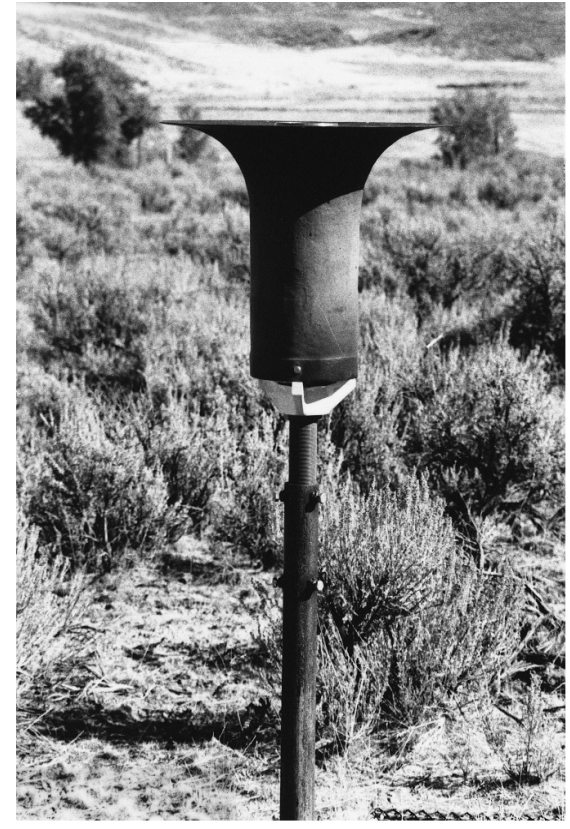

(f)

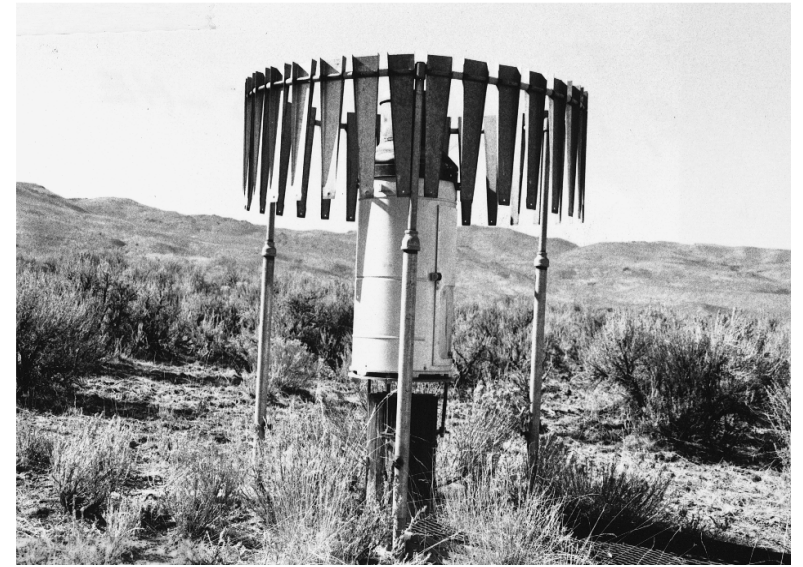

FIG. 3. Precipitation Gauges: (a) Belfort Universal Recording Gauge with Wyoming Shield; (b) DFIR Gauge; (c) TRET Gauge with Shield; (d) Canadian Nipher Shielded Snow Gauge; (e) in Foreground Is U.S. National Weather Service 8-in. Nonrecording Gauge, and in Background Are Two Belfort Universal Recording Gauges with Orifices at 3.05 m, One with Constrained-Baffle Alter-Type Shield; (f) Belfort Universal Recording Gauge with Unconstrained-Baffle Alter Shield

\section{Snow}

As shown in Table 1, the computed snow catch from the DUAL-GAUGE system and the CAN catch were greater than the WYO catch, by 4 and $1 \%$, respectively. The greater catch of snow by the DUAL-GAUGE system supports previ- ous findings by Hanson (1989). The DFIR and NATSHLD catches were only 2 and $4 \%$ less, respectively, than the WYO catch. The TRET and BELSHLD caught approximately $10 \%$ less snow than the WYO. The NATUNSHLD and the BELUNSHLD gauges caught 12 and 24\% less, respectively, 
TABLE 1. Total Gauge Catch (mm) for 1987-1994 Winter Periods, Reynolds Creek, Idaho

\begin{tabular}{|c|c|c|c|c|c|c|c|c|c|}
\hline \multirow{2}{*}{$\begin{array}{c}\text { Precipitation } \\
\text { type } \\
\text { (1) }\end{array}$} & \multicolumn{9}{|c|}{ Gauge } \\
\hline & $\begin{array}{l}\text { WYO } \\
(2)\end{array}$ & $\begin{array}{c}\text { DFIR } \\
(3)\end{array}$ & $\begin{array}{l}\text { TRET } \\
(4)\end{array}$ & $\begin{array}{l}\text { CAN } \\
(5)\end{array}$ & $\begin{array}{l}\text { NATUNSHLD } \\
(6)\end{array}$ & $\begin{array}{l}\text { NATSHLD } \\
(7)\end{array}$ & $\begin{array}{c}\text { BELUNSHLD } \\
(8)\end{array}$ & $\begin{array}{l}\text { BELSHLD } \\
(9)\end{array}$ & $\begin{array}{c}\text { DUAL-GAUGE } \\
(10)\end{array}$ \\
\hline $\begin{array}{l}\text { Snow }(N=49) \\
\text { Ratio }\end{array}$ & $211.8 b$ & $\begin{array}{r}207.2 \mathrm{c} \\
0.98\end{array}$ & $\begin{array}{r}191.6 \mathrm{~d} \\
0.90\end{array}$ & $\begin{array}{r}213.3 \mathrm{~b} \\
1.01\end{array}$ & $\begin{array}{r}187.3 \mathrm{~d} \\
0.88\end{array}$ & $\begin{array}{r}202.3 c \\
0.96\end{array}$ & $\begin{array}{r}160.4 \mathrm{e} \\
0.76\end{array}$ & $\begin{array}{r}192.1 \mathrm{~d} \\
0.91\end{array}$ & $\begin{array}{r}220.9 \mathrm{a} \\
1.04\end{array}$ \\
\hline $\begin{array}{l}\text { Mixed }(N=23) \\
\quad \text { Ratio }\end{array}$ & $118.7 \mathrm{a}$ & $\begin{array}{c}115.40 \mathrm{a} \\
0.97\end{array}$ & $\begin{array}{c}110.50 \mathrm{~b} \\
0.93\end{array}$ & $\begin{array}{c}115.10 \mathrm{a} \\
0.97\end{array}$ & $\begin{array}{c}107.90 \mathrm{~b} \\
0.91\end{array}$ & $\begin{array}{c}115.20 \mathrm{a} \\
0.97\end{array}$ & $\begin{array}{r}97.60 \mathrm{c} \\
0.82\end{array}$ & $\begin{array}{c}107.50 \mathrm{~b} \\
0.91\end{array}$ & $\begin{array}{c}115.50 \mathrm{a} \\
0.97\end{array}$ \\
\hline $\begin{array}{l}\text { Rain }(N=37) \\
\quad \text { Ratio }\end{array}$ & $178.7 \mathrm{a}$ & $\begin{array}{r}170.0 \mathrm{~b} \\
0.95\end{array}$ & $\begin{array}{c}164.3 \mathrm{~cd} \\
0.92\end{array}$ & $\begin{array}{c}167.5 b c \\
0.94\end{array}$ & $\begin{array}{c}167.0 b c \\
0.93\end{array}$ & $\begin{array}{r}174.5 b \\
0.98\end{array}$ & $\begin{array}{r}160.6 \mathrm{~d} \\
0.90\end{array}$ & $\begin{array}{r}165.3 \mathrm{c} \\
0.93\end{array}$ & $\begin{array}{c}168.7 b c \\
0.94\end{array}$ \\
\hline $\begin{array}{l}\text { Total }(N=109) \\
\quad \text { Ratio }\end{array}$ & $509.2 \mathrm{a}$ & $\begin{array}{c}492.60 \mathrm{~b} \\
0.97\end{array}$ & $\begin{array}{c}466.40 \mathrm{c} \\
0.92\end{array}$ & $\begin{array}{c}495.90 \mathrm{ab} \\
0.97\end{array}$ & $\begin{array}{c}462.20 \mathrm{c} \\
0.91\end{array}$ & $\begin{array}{c}492.00 \mathrm{~b} \\
0.97\end{array}$ & $\begin{array}{c}418.60 \mathrm{~d} \\
0.82\end{array}$ & $\begin{array}{c}464.90 \mathrm{c} \\
0.91\end{array}$ & $\begin{array}{c}505.10 \mathrm{ab} \\
0.99\end{array}$ \\
\hline
\end{tabular}

Note. The mean values of rows with the same letter were not significantly different at the 0.05 probability level. Ratio $=$ gauge catch values/WYO catch.

than the WYO snow catch. Snow catch by the BELUNSHLD was significantly less than the catch by any of the other gauging systems.

In their Nebraska study, Allis et al. (1963) found that for snowfall events, unshielded gauges that had been installed according to U.S. Weather Bureau specifications caught approximately $70 \%$ of shielded gauges. They also found that the catch by a standard U.S. Weather Bureau unshielded gauge mounted with the orifice at $1.83 \mathrm{~m}$ only caught approximately $50 \%$ of the shielded gauges that had been installed according to U.S. Weather Bureau specifications. These results again emphasize the fact that shielded gauges that are installed correctly are required for the most reliable snowfall measurement.

\section{Mixed Snow and Rain}

In the mixed precipitation category, all of the other gauging systems caught less than the WYO. However, four of the gauging systems, the DFIR, CAN, NATSHLD, and DUALGAUGE were all within $3 \%$ of the WYO catch, which was not significantly different from the WYO catch. This would suggest that these gauges can be used to measure mixed precipitation about as well as the WYO at this location. The TRET, NATUNSHLD, and BELSHLD catches were between 91 and $93 \%$ of the WYO catch. As with snow, the BELUNSHLD had the least catch ( $82 \%$ of WYO), which was significantly less than any of the other gauging systems.

Allis et al. (1963) reported that an unshielded, standard U.S. Weather Bureau gauge caught approximately $88 \%$ of shielded gauges and that the unshielded, standard U.S. Weather Service gauge mounted with the orifice at $1.83 \mathrm{~m}$ caught approximately $80 \%$ of the shielded gauges. Hanson (1989) found that the BELSHLD and BELUNSHLD caught 12 and 22\%, respectively, less than the WYO for mixed events only. The results found in this study agree well with the results from the previous two studies.

\section{Rain}

For rainfall, the WYO had a statistically significant greater catch than any of the other gauging systems. The NATSHLD was the only gauging system that caught within $2 \%$ of that measured by the WYO. All of the other gauging systems, except the BELUNSHLD gauge, had a rainfall undercatch between 5 and $8 \%$. The BELUNSHLD had less catch than any of the other gauging systems but the difference was less than for snow or mixed events. The BELUNSHLD gauge most likely had less catch than any of the other gauges because of the combined effects of lack of shielding and its greater height above the ground, where wind effects are greater.

The results from this study agree with those reported by Allis et al. (1963) where they found an undercatch of approximately $3 \%$ between shielded and unshielded gauges. Hanson
(1989) reported an undercatch of approximately $8 \%$ for the BELUNSHLD system.

\section{Total Precipitation}

For all precipitation types and events combined (total in Table 1), the WYO caught more precipitation than any of the other gauges; however, the undercatch was only $3 \%$ or less for the DFIR, CAN, NATSHLD, and DUAL-GAUGE. The catch by the WYO, CAN, and DUAL-GAUGE were not significantly different. These results indicate that these five gauging systems may be used with little or no correction but there may be a small undercatch relative to the WYO. The TRET, NATUNSHLD, and BELSHLD caught between 8 and 9\% less total precipitation than the WYO. It should be noted here that the BELSHLD and the NATSHLD gauges are the same type of gauge and both were shielded; however, the BELSHLD orifice was at $3.05 \mathrm{~m}$, which most likely accounted for most of the difference in catch between these two gauges. The BELUNSHLD, with its orifice at $3.05 \mathrm{~m}$, caught $18 \%$ less precipitation than the WYO gauge, which was significantly less than any of the other gauging systems.

\section{Effect of Wind Speed on Ratio between Other Gauge Catches and WYO Catch}

Snow

Analyses of snowfall events showed that wind speed had no significant effect on snowfall catch ratio between the WYO and the CAN or DUAL-GAUGE systems (Table 2). The other six gauging systems caught significantly lesser amounts of snow than the WYO as wind speeds increased. As would be expected from previous discussion, the DFIR and NATSHLD were the least affected by wind of these six systems. The TRET, NATUNSHLD, and BELSHLD catch were all affected by wind more than the aforementioned systems, but not to the extent of the BELUNSHLD. The BELUNSHLD undercatch is illustrated dramatically in Fig. 4, which shows the catch ratio between the BELUNSHLD and the WYO related to wind speed. The BELUNSHLD undercaught at all wind speeds and by as much as $75 \%$.

The results for the BELSHLD agree quite well with a previous study by Hanson (1989). However, in the present study, the BELUNSHLD system had a somewhat greater undercatch in comparison with the WYO as wind speed increased.

\section{Mixed Snow and Rain}

Less consistency was noted in the wind effect on the various gauging systems' mixed catch than was observed for snow or rain. Examples of this inconsistency are found for the BELUNSHLD where the slope of the regression line is not significantly different from 0.0 for mixed precipitation and is 
TABLE 2. Regression Analyses of Ratio of WYO and Other Gauges (Gauge Catch/WYO Catch) and Wind Speed (m/s) at $3 \mathrm{~m}$

\begin{tabular}{|c|c|c|c|c|c|c|c|c|c|c|c|c|}
\hline \multirow[b]{4}{*}{$\begin{array}{c}\text { Gauge } \\
(1)\end{array}$} & \multicolumn{12}{|c|}{ Type of precipitation } \\
\hline & \multicolumn{4}{|c|}{ SNOW $(N=49)$} & \multicolumn{4}{|c|}{ MIXED $(N=23)$} & \multicolumn{4}{|c|}{ RAIN $(N=37)$} \\
\hline & \multirow[b]{2}{*}{$\begin{array}{l}\text { Relationship } \\
(2)\end{array}$} & \multicolumn{3}{|c|}{ Significant } & \multirow[b]{2}{*}{$\begin{array}{c}\text { Relationship } \\
(6)\end{array}$} & \multicolumn{3}{|c|}{ Significant } & \multirow[b]{2}{*}{$\begin{array}{l}\text { Relationship } \\
\text { (10) }\end{array}$} & \multicolumn{3}{|c|}{ Significant } \\
\hline & & $\begin{array}{c}R \\
(3) \\
\end{array}$ & $\begin{array}{c}\text { Slope } \\
(4)\end{array}$ & $\begin{array}{c}\text { Intercept } \\
(5)\end{array}$ & & $\begin{array}{c}R \\
(7) \\
\end{array}$ & $\begin{array}{c}\text { Slope } \\
(8)\end{array}$ & \begin{tabular}{|c|} 
Intercept \\
$(9)$
\end{tabular} & & $\begin{array}{c}R \\
(11) \\
\end{array}$ & $\begin{array}{c}\text { Slope } \\
(12)\end{array}$ & $\begin{array}{c}\text { Intercept } \\
(13)\end{array}$ \\
\hline DFIR & $Y=1.001-0.025 X$ & -0.291 & $\mathrm{~S}$ & $\mathrm{~N}$ & $Y=1.069-0.028 X$ & -0.654 & $S$ & $S$ & $Y=1.076-0.036 X$ & -0.433 & $S$ & $\mathrm{~N}$ \\
\hline TRET & $Y=0.997-0.074 X$ & -0.621 & S & $\mathrm{N}$ & $Y=0.996-0.023 X$ & -0.488 & S & $\mathrm{N}$ & $Y=1.019-0.035 X$ & -0.367 & $\mathrm{~S}$ & $\mathrm{~N}$ \\
\hline CAN & $Y=1.011-0.001 X$ & -0.011 & $\mathrm{~N}$ & $\mathrm{~N}$ & $Y=0.981-0.003 X$ & -0.051 & $\mathrm{~N}$ & $\mathrm{~N}$ & $Y=1.098-0.046 X$ & -0.550 & S & S \\
\hline NATUNSHLD & $Y=0.975-0.073 X$ & -0.713 & $\mathrm{~S}$ & $\mathrm{~N}$ & $Y=1.017-0.031 X$ & -0.573 & S & $\mathrm{N}$ & $Y=0.987-0.017 X$ & -0.197 & $\mathrm{~N}$ & $\mathrm{~N}$ \\
\hline NATSHLD & $Y=0.972-0.016 X$ & -0.314 & $\mathrm{~S}$ & $\mathrm{~N}$ & $Y=0.930+0.005 X$ & +0.112 & $\mathrm{~N}$ & $\mathrm{~N}$ & $Y=0.963-0.001 X$ & -0.032 & $\mathrm{~N}$ & $\mathrm{~N}$ \\
\hline BELUNSHLD & $Y=0.901-0.094 X$ & -0.808 & $\mathrm{~S}$ & $\mathrm{~S}$ & $Y=0.831-0.009 X$ & -0.184 & $\mathrm{~N}$ & $S$ & $Y=0.964-0.022 X$ & -0.462 & $\mathrm{~S}$ & $\mathrm{~N}$ \\
\hline BELSHLD & $Y=0.980-0.054 X$ & -0.708 & $\mathrm{~S}$ & $\mathrm{~N}$ & $Y=0.941-0.014 X$ & -0.420 & $\mathrm{~S}$ & $\mathrm{~N}$ & $Y=0.971-0.016 X$ & -0.408 & $\mathrm{~S}$ & $\mathrm{~N}$ \\
\hline $\begin{array}{l}\text { DUAL- } \\
\text { GAUGE }\end{array}$ & $Y=1.025+0.001 X$ & +0.016 & $\mathrm{~N}$ & $\mathrm{~N}$ & $Y=1.028-0.017 X$ & -0.526 & $S$ & $\mathrm{~N}$ & $Y=0.978-0.011 X$ & -0.244 & $\mathrm{~N}$ & $\mathrm{~N}$ \\
\hline
\end{tabular}

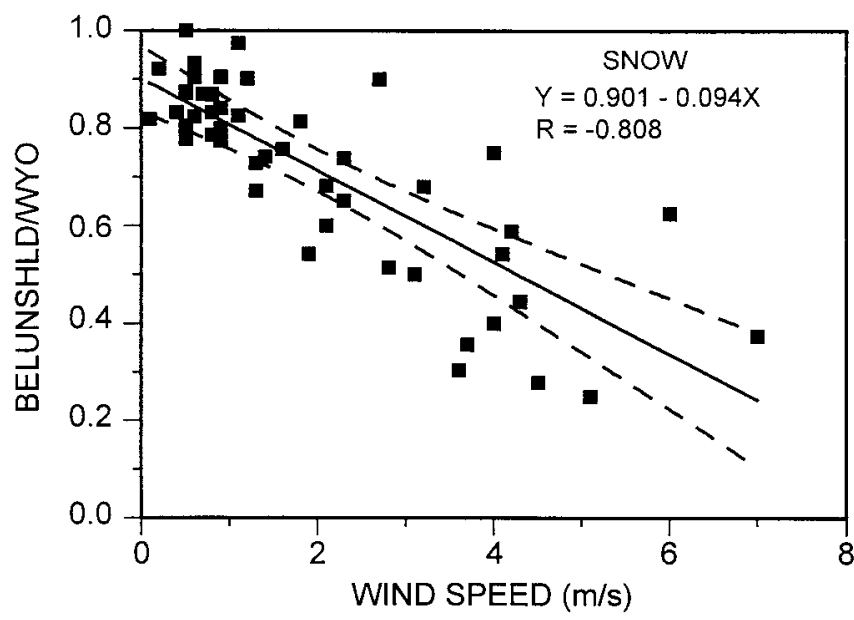

FIG. 4. Relationship between BELUNSHLD/WYO Snow Catch Ratio and Wind Speed

for both snow and rain. Just the opposite result is shown for the DUAL-GAUGE, where the slope of the regression line is significantly different from 0.0 for mixed precipitation and not for either snow or rain. This lack of consistency may be caused by fewer numbers of events (23) and because wind and gauge shielding affect rain and snow catch differently. No significant relationship was noted between the WYO catch and either the CAN or the NATSHLD catch, but all other gauging systems did reflect wind speed dependence.

\section{Rain}

Wind speed had no discernible effect on gauge catch ratios (relative to the WYO catch) during rain events for the NATUNSHLD, NATSHLD, and DUAL-GAUGE systems. The CAN caught significantly more rain than the WYO at very low wind speeds and less at higher wind speeds, with the net effect that the CAN caught significantly less total rain (Table 1) than the WYO. The DFIR, TRET, BELUNSHLD, and BELSHLD all caught significantly lesser amounts of rain than the WYO as wind speeds increased. These results agree with earlier studies by Allis et al. (1963), Hanson (1989), and Neff (1977), which showed that gauge shielding is required for the most accurate measurement of rain.

\section{CONCLUSIONS}

In this study, precipitation catch relationships among nine gauging systems were investigated. Precipitation events of 1.5 $\mathrm{mm}$ and greater that were divided into groups of snow, mixed snow and rain, and rain were used in this study. The WYO was used as the basis of the comparison because it had the greatest mixed, rain, and total catches. The following are a summary of the results of our study:

1. The calculated snowfall from the DUAL-GAUGE system was significantly greater than for any of the other systems. The WYO and the CAN caught approximately $4 \%$ less than the DUAL-GAUGE. The DFIR and the NATSHLD had catches within $4 \%$ of the WYO. The other gauges caught more than $8 \%$ less than the WYO. The BELUNSHLD caught $76 \%$ of the WYO catch.

2. For mixed snow and rain, there was no significant difference in catch between the WYO, DFIR, CAN, NATSHLD, and DUAL-GAUGE. The TRET caught 7\% less and the NATUNSHLD and BELSHLD each caught 9\% less than the WYO. The BELUNSHLD had the greatest undercatch, which was $18 \%$ less than the WYO.

3. The WYO caught significantly more rain than any of the other gauging systems; however, the catch by the DFIR, CAN, NATUNSHLD, NATSHLD, and DUAL-GAUGE were all within $7 \%$ of the WYO. The BELUNSHLD had the lowest catch $(90 \%$ of the WYO).

4. The WYO caught the most total precipitation of all systems, but this was not significantly greater than the catch by the CAN or DUAL-GAUGE systems. The DFIR, CAN, NATSHLD, and DUAL-GAUGE all caught within $3 \%$ of the WYO. The TRET, NATUNSHLD and the BELSHLD undercaught between 8 and $9 \%$ of the WYO. The total BELUNSHLD catch was $18 \%$ less than the WYO.

5. Wind speed had a small effect on the catch ratio between the DUAL-GAUGE and WYO systems and did not affect the catch ratio of snow and mixed precipitation between the WYO and the CAN systems. Compared with the WYO, all other gauging systems, except for the NATSHLD, had decreased catch with increasing wind speed for all precipitation categories, with the largest differences during snow events.

6. At this location, the NATSHLD system's catch was $96 \%$ or greater of the WYO system for all of the precipitation categories. Also, wind had only small effects on NATSHLD catch ratio with WYO. This would suggest that this system may be a reliable, cost-effective approach to measuring precipitation at locations with similar environments.

7. These results again emphasize that precipitation gauge shielding and the location of the orifice above the ground are critical to reliable precipitation measurements.

8. The results from this study support the concept of correcting precipitation catch when different types of gauging systems are used and for other precipitation-measuring errors such as the effects of wind as discussed by 
Legates and DeLiberty (1993), Legates and Willmott (1990), Sevruk (1982), and in the papers from the workshop edited by Sevruk (1986).

\section{APPENDIX. REFERENCES}

Allis, J. A., Harris, B., and Sharp. A. L. (1963). "A comparison of performance of five rain-gage installations.' J. Geophys. Res., 68, 47234729 .

Alter, J. C. (1937). "Shielded storage precipitation gages.' Monthly Weather Rev., 65, 262-265.

Arnell, N., et al. (1996). "Hydrology and freshwater ecology." Climate change 1995, impacts, adaptations and mitigation of climate change: scientific-technical analyses, R. T. Watson, M. C. Zinyowera, R. H. Moss, and D. J. Dokken, eds., Cambridge University Press, Cambridge, Great Britain, 325-363.

Canadian Department of Environment (1985). "Measuring snowfall water equivalent using the Nipher shielded snow gauge system." Rep. No. IB 04-03-01/1, Atmospheric Environment Service, Canadian Department of Environment, Ottawa, Canada.

Flerchinger, G. N., Hanson, C. L., and Burgess, M. (1994). "Reynolds Creek Experimental Watershed, Idaho.” 1994 Int. Summer Meeting, Paper No. 94-2167, American Society of Agricultural Engineers, St. Joseph, Mich.

Garstka, W. U. (1964). "Snow and snow survey." Handbook of applied hydrology, a compendium of water-resources technology, V. T. Chow, ed., McGraw-Hill, Inc., New York, 10-1-10-57.

Goodison, B., Sevruk, B. E., and Klemm, S. (1989). "WMO solid precipitation measurement intercomparison: Objectives, methodology, analysis.' Atmospheric Deposition, IASH Publ. No. 179, International Association of Hydrologic Science, Gentbrugge, Belgium, 57-64.

Hamon, W. R. (1973). "Computing actual precipitation; distribution of precipitation in mountainous areas,', Vol. 1, WMO Rep. No. 362, World Meteorological Organization, Geneva, Switzerland.

Hanson, C. L. (1989). "Precipitation catch measured by the Wyoming shield and the dual-gage systems.' Water Resour. Bull., 25, 159-164.

Hanson, C. L., Johnson, G. L., McFarland, M. J., Gebhardt, K., and Smith, J. A. (1996). "Chapter 2, Precipitation.' Hydrology handbook, Committee on Hydrology Handbook, ed., American Society of Civil Engineers, New York, 5-74.

Israelson, C. E. (1967). Reliability of can-type precipitation gage measurements, a state-of-the-science study. Utah State University, Logan, Utah.

Kurtyka, J. C. (1953). "Precipitation measurement study." Illinois State Water Survey, Report of Investigation No. 20. State Water Survey Division, Urbana, Ill.

Larson, L. W. (1971). "Precipitation and its measurement: A state-of-the- art." Water Resour. Ser. No. 24, Water Resources Research Institute, University of Wyoming, Laramie, Wyo.

Legates, D. R., and DeLiberty, T. L. (1993). "Precipitation measurement biases in the United States.' Water Resour. Bull., 29, 855-861.

Legates, D. R., and Willmott, C. J. (1990). "Mean seasonal and spatial variability in gauge-corrected, global precipitation.' Int. J. Climatology, 10, $111-127$.

Neff, E. L. (1977). "How much rain does a rain gage gage?', J. Hydro., Amsterdam, 35, 213-220.

Nicholls, N., et al. (1996). "Observed climate variability and change.", Climate change 1995, the science of climate change, J. T. Houghton, L. G. Meira Filho, B. A. Callander, N. Harris, A. Kattenberg, and K. Maskell, eds., Cambridge University Press, Cambridge, Great Britain, $133-192$.

Rechard, P. A. (1975). "Measurement of winter precipitation in windswept areas.' Symp. of Snow Mngmt. on the Great Plains, Bismarck, N.D., Great Plains Agric. Council, Pub. No. 73, University of Nebr., Lincoln, Nebr., 13-30.

Robins, J. S., Kelly, L. L., and Hamon, W. R. (1965). "Reynolds Creek in southwest Idaho: An outdoor hydrologic laboratory.' Water Resour. Res., 1, 407-413.

Sevruk, B. (1982). "Methods of correction for systematic error in point precipitation measurement for operational use.' Operational Hydro. Rep. No. 21, WMO No. 589, World Meteorological Organization, Geneva, Switzerland.

Sevruk, B., ed. (1986). "Correction of precipitation measurements." ETH/IAHS/WMO Workshop on the Correction of Precipitation Measurements, Geographische Institut, Eidgenossische Technische Hochschule, No. 23, Zurich, 289.

Sevruk, B., and Klemm, S. (1989). "Types of standard precipitation gauges.' Precipitation Measurement, WMO/IASH/ETH Workshop on Precipitation Measurement, B. Sevruk, ed., Swiss Federal Institute of Technology, ETH-Zentrum, CH-8092 Zurich, 227-232.

Siegel, S. (1956). Nonparametric statistics for the behavioral sciences. McGraw-Hill, New York.

Snedecor, G. W., and Cochran, W. G. (1967). Statistical methods. Iowa University Press, Ames, Iowa.

StatMost. (1995). Statistical analysis and graphics: user's guide. DataMost Corp., Salt Lake City, Utah.

Stephenson, G. R. (1977). "Soil-geology-vegetation inventories for Reynolds Creek Watershed." Agric. Experiment Station, Miscellaneous Ser. No. 42, University of Idaho, Moscow, Idaho.

Warnick, C. C. (1953). "Experiments with windshields for precipitation gages." Trans. Am. Geophysical Union, 34, 379-388.

Weiss, L. L., and Wilson, W. T. (1958). "Precipitation gage shields." Int. Assoc. of Scientific Hydro., Publ. No. 43, 1, General Assembly of Toronto, ON, Canada, 462-484. 